This item was submitted to Loughborough's Research Repository by the author.

Items in Figshare are protected by copyright, with all rights reserved, unless otherwise indicated.

\title{
Sustainability aspects of using geotextiles
}

PLEASE CITE THE PUBLISHED VERSION

http://store.elsevier.com/Geotextiles/Robert-Koerner/isbn-9780081002216/

\section{PUBLISHER}

Woodhead Publishing / @ Elsevier

VERSION

AM (Accepted Manuscript)

\section{PUBLISHER STATEMENT}

This work is made available according to the conditions of the Creative Commons Attribution-NonCommercialNoDerivatives 4.0 International (CC BY-NC-ND 4.0) licence. Full details of this licence are available at: https://creativecommons.org/licenses/by-nc-nd/4.0/

\section{LICENCE}

CC BY-NC-ND 4.0

\section{REPOSITORY RECORD}

Dixon, Neil, Jamil Raja, Gary John Fowmes, and Matthew W. Frost. 2019. "Sustainability Aspects of Using Geotextiles". figshare. https://hdl.handle.net/2134/21122. 


\title{
Chapter 27: Sustainability Aspects of Using Geotextiles
}

\author{
Dixon $^{1}$, Raja, Fowmes, Frost
}

School of Civil and Building Engineering, Loughborough University, UK, ${ }^{1}$ Corresponding author n.dixon@lboro.ac.uk

\begin{abstract}
Sustainability of materials and processes are commonly assessed by calculating the carbon emissions $\left(\mathrm{CO}_{2}\right)$ generated. This is a simplification but the ease of calculation encourages comparisons of solutions, makes outputs of assessments accessible, transparent and repeatable, and $\mathrm{CO}_{2}$ savings can readily be counted towards industry, national and international targets. This chapter describes a framework for calculating embodied carbon of construction solutions that incorporate geotextiles. It outlines carbon footprinting techniques and common definitions, presents examples of embodied carbon for geotextile materials, defines life cycle boundaries and presents example calculations for common construction case studies: Protection, working platform and landfill capping. All three examples demonstrate the significant $\mathrm{CO}_{2}$ savings that can result from employing geotextiles. These savings are realised through reducing the amount of imported fill material used and this minimises the transport related carbon emissions. The approach introduced can be used to undertake site specific calculations that inform decisions on selection of construction approaches that contribute to sustainable practice.
\end{abstract}

Keywords: Sustainability, Carbon Emissions, Embodied Carbon, Life Cycle Analysis, Carbon Footprinting

\subsection{Introduction}

Sustainability is a widely used term, often with many differing meanings. The definition adopted in this chapter shall align with that of Brundtland, (1987) as: "development that meets the needs of the present without compromising the ability of future generations to meet their own needs". The chapter considers the key indicators of sustainability, especially focusing on $\mathrm{CO}_{2}$ emissions, to provide a framework for assessing sustainability of a construction projects, and it provides examples of how geotextiles, when used correctly and efficiently, can improve the sustainability credentials of an engineered solution.

\subsection{Drivers for sustainable development}

Climate change is an issue that has been at the forefront of global discussions for many years, however, it has now become one of the biggest challenges the world faces. There is a body of overwhelming scientific evidence that links increasing greenhouse gases (GHG) and $\mathrm{CO}_{2}$ emissions with the changing climate (EPA, 2014). The need to act on rising $\mathrm{CO}_{2}$ emissions dates back to 1988 when the United Nations Environment Programme (UNEP) and World Meteorological Organisation (WMO) formed the Intergovernmental Panel on Climate Change (IPCC) to provide the world with a clear scientific view on climate change and its potential impacts (IPCC, 2014). The decision to act on $\mathrm{CO}_{2}$ emissions was further strengthened in 1992 with the formation of the United Nations 
Framework Convention on Climate Change (UNFCCC). The UNFCCC is an international treaty that countries (parties) joined, to support efforts to tackle the issues of climate change (United Nations, 1992). The parties to the convention recognized that measures to reduce emissions were insufficient and hence this led to the setting of legally binding emissions targets in the form of the Kyoto Protocol (United Nations, 1998). Due to a complex approval procedure the protocol eventually came into effect in 2005 and set emissions commitments on 37 industrialized nations which included the European Union member states and Australia amongst others. This has led these nations to bring in their own legislation and emission reduction targets. Examples include the Emissions Trading System (ETS) set by the European Union (2013) and 'The Climate Change Act 2008' legislation set by the UK government (TSO, 2008). The main factor driving the push to reduce $\mathrm{CO}_{2}$ emissions is the recognition globally that increased $\mathrm{CO}_{2}$ emissions are accountable for the changing climate.

Whilst many definitions and elements of sustainability exist, the use of $\mathrm{CO}_{2}$ emissions has been recognised in international treaties and national and international policies, therefore, $\mathrm{CO}_{2}$ is often used as a marker of sustainability of a project. Moreover, there is a need for this simplification of the assessment of sustainability to encourage comparisons to be carried out and to increase the accessibility, transparency, repeatability and rigour of sustainability assessment. Embodied carbon is employed in the remainder of this chapter as an indicator of the sustainability of an engineered system.

\subsection{Sustainability assessment criteria}

The $\mathrm{CO}_{2}$ and cost saving benefits of solutions that employed geosynthetics were highlighted in a study by the UK Waste and Action Resources Programme (WRAP). WRAP (2010) carried out a number of case studies that compared differing solutions and showed how the use of geosynthetics amongst other benefits can also reduce the amount of imported fill. This provided $\mathrm{CO}_{2}$ savings from the embodied carbon emissions of quarrying of the fresh fill as well as that from the transportation of these materials on and off site. Although the WRAP study showed significant cost and $\mathrm{CO}_{2}$ savings of employing geosynthetics it was limited in scope to the function of soil reinforcement. It also did not extend the Life Cycle Analysis (LCA) boundaries to cover construction emissions as this was assumed negligible in most instances (cradle to gate). Similar studies have also been carried out by the European Association of Geosynthetic Manufacturers (EAGM) (Stucki et al., 2011) and Heerten (2012). These studies, unlike the WRAP study, extended LCA boundaries to cradle to grave, and they hence they differ in scope. The work by Heerten (2012) complimented the results of the WRAP study as it highlighted the $\mathrm{CO}_{2}$ savings of employing geosynthetic solutions in applications such as steep slopes and roads, however the study was again limited to the function of reinforcement.

The EAGM study titled 'Comparative Life Cycle Assessment of Geosynthetics versus Conventional Construction Materials' (Stucki et al., 2011) provided comprehensive qualitative and quantitative information on the environmental performance of commonly applied construction materials (i.e. concrete) versus geosynthetics. It compared geosynthetic solutions against conventional (traditional) solutions using eight environmental impact indicators:

1. Cumulative Energy Demand,

2. Climate Change (Global Warming Potential),

3. Photochemical Ozone Formation, 

4. Particulate Formation,
5. Acidification,
6. Eutrophication,
7. Land Competition and
8. Water Use

The study reports four construction systems/cases; filter layer, foundation stabilisation , landfill construction and slope retention and while WRAP (2010) employed actual projects for its case studies the EAGM study was based on hypothetical designs, with the functional unit of the specific construction defined for each case. All cases considered were designed so that both the geosynthetic and conventional solutions were technically equivalent. For example in the filter layer case study, Stucki et al. (2011) define the functional unit as 'The construction and disposal of a filter with an area of 1 square meter, with a hydraulic conductivity (k-value) of $0.1 \mathrm{~mm} / \mathrm{s}$ or more and a life time of 30 years'. Furthermore, the study employs LCA boundary conditions of cradle to grave. This is another notable difference to the WRAP (2010) study as it accounts for environmental impact from LCA stages such as construction and disposal.

\subsection{Carbon footprinting}

A carbon footprint can be defined as the total $\mathrm{CO}_{2}$ emissions produced by an organisation, activity, project, product, event or person. Carbon footprinting is the method employed in measuring such emissions and the level of impact they have on the environment. The scope of carbon footprinting can range from very large scale measurement at a global level to a finer product based scale. Carbon footprinting of a construction project/method allows the embodied carbon of the materials used to be combined with $\mathrm{CO}_{2}$ emissions from processes such as transport of materials/waste and plant used in the construction process. The availability of material embodied carbon values allows those carrying out the carbon footprinting to build up calculated values by including emissions for construction, use and disposal as required for designated boundary conditions. Carbon footprinting has no specific definition or generalised process, and is based on the criteria set and level of analysis required. Factors such as the assessment boundary conditions (see Section 27.9 on LCA) employed will govern the extent, detail and scope of the carbon footprinting calculations.

\subsection{Embodied carbon and embodied energy}

The embodied carbon (EC) of a material can be defined as the amount of $\mathrm{CO}_{2}$ emissions released in the extraction, manufacture and transport of the material. Often in reported EC studies the term embodied energy (EE) is used interchangeably with EC, depending on what form of analysis is being undertaken. EE of a material can be easily measured using appropriate energy meters, such as the electricity used on a production line. These EE values can then be converted to EC values using appropriate conversion factors derived from knowledge of the processes used to make the energy. The conversion factor will be different for different energy mixes (e.g. coal, nuclear or renewable) used in the manufacturing process (DEFRA 2013). EE values provide a comparison of the efficiency of manufacturing processes but the factors used to convert these to EC values are typically outside of the manufacturer's control. Conversion is required because EC values are more useful as they allow comparisons between geosynthetic construction solutions, especially where components are derived 
from global markets often with differing energy mixes. Where the embodied carbon values are obtained from calculated embodied energy, the unit descriptor is $\mathrm{tCO}_{2} \mathrm{e} / \mathrm{t}$.

\subsection{Embodied Carbon for Geosynthetic Products}

In order to carry out an LCA analysis for construction solutions containing geosynthetics, accurate embodied carbon data is required for those geosynthetic materials. Several sources of generic EE/EC exist. Two of the widely used sources include the Inventory of Carbon \& Energy (ICE) database (Hammond and Jones, 2011) and the European life cycle analysis database called 'Ecolnvent v3.0' (Ecolnvent Centre, 2013). The ICE database specifically focuses on the EE/EC of materials, whereas the Ecolnvent provides data for a wide range of life cycle indicators ranging from global warming to eutrophication. So although Ecolnvent can be used to source EC data, it is particularly applicable for use in Life Cycle Assessments similar to those carried out by the EAGM (Stucki et al., 2011).

At the time of writing there is very limited open source material on the embodied energy or embodied carbon for geosynthetic materials. Whilst some manufacturers quote values for their materials embodied energy, there is limited transparency in the derivation of these values. The accuracy of the EC values used in assessment of projects ultimately affects the validity of the carbon footprinting undertaken. If different assumptions are made, ambiguity is introduced to the accuracy of EC values and the decisions made using this information.

Geosynthetic products have no specific representation in the ICE or Ecolnvent databases. This means that when carbon footprinting geosynthetic products the EC data applied are generic values for plastic materials, and not product specific information obtained from the manufacturing process. An example is sourcing a value for a polypropylene (PP) based geotextile from the ICE database. It can be seen from Table 27.1 that there are three possible alternatives for a value of PP in the ICE and Ecolnvent databases, however none of the values specifically represent a geotextile. It is arguable that the manufacturing processes included in the calculation of embodied carbon for orientated film or injection moulded products included in ICE are not applicable for geotextiles and the granules value in Ecolnvent does not include any product processing emissions. Use of these generic values in a carbon footprinting analysis of a geosynthetic construction solution will give incorrect and inconsistent results. This degree of variability and uncertainty could lead to challenges of the validity of such calculations from those outside the geosynthetic industry, if the geosynthetic based solution is shown to be more sustainable. EC values for other polymers are also included in Table 27.1 for comparison.

Table 27.1 Embodied carbon values for different plastics from ICE (Hammond \& Jones, 2011) and Ecolnvent v2.2 (Ecolnvent Centre, 2010)

\subsection{Embodied Carbon for Geotextiles}

A recent case study reported by Raja et al (2015) has produced embodied carbon data for two geotextile product ranges produced by two different manufacturers. Raja et al (2015) used the embodied energy values from the Ecolnvent database to provide a cradle to gate embodied carbon value for PP granules (Ecolnvent, 2010), which are used to manufacture staple fibres. This value was then combined with the amount of carbon produced in the manufacture of the geosynthetic products to give an overall embodied carbon value. The two manufacturers employed different 
processes with one making needle-punched products and the other predominately making thermal bonded geotextile, although a few of the production lines employed a mixture of both methods. Energy used in the production of geotextile products, including conversion of PP pellets to staple fibres and staple fibres to geotextile sheets, was measured using electrical energy meters at the supply source of the manufacturing lines and the amount of energy consumed per $\mathrm{kg}$ of material produced was calculated. This measurement procedure was repeated for products with a range of masses per unit area in order to provide data for a variety of commonly used products. Full details of the procedure are provided by Raja et al. (2015). The calculation method also included pre-gate transport emissions for the movement of component parts, e.g. granules or fibres, to the geotextile manufacturing plant. The approach assumed the use of road transport (20t rigid Heavy Goods Vehicle) with a fuel consumption of $3.33 \mathrm{~km} / / \mathrm{tr}$ (Department for Transport, 2012). This in conjunction with a $\mathrm{CO}_{2}$ emissions value for diesel of $2.60 \mathrm{kgCO}_{2}$ per litre of fuel (DEFRA, 2013) and typical material transport distances were employed in Equation 27.1. The calculated EC values are shown in Table 27.2 for the set of assumptions used. An output of the calculations is that transport of the PP material to the production plant produces very little in terms of $\mathrm{CO}_{2}$ emissions when compared to the embodied carbon of the raw polymer. For the Raja et al (2015) case study the pre-gate transport emissions for the PP used to manufacture the geotextiles were less than $0.007 \mathrm{tCO}_{2} / \mathrm{t}$.

$$
C=\frac{\beta(2 D / \alpha)}{1000 Q}
$$

Where $\mathrm{C}=$ Total $\mathrm{CO}_{2}$ emissions per tonne $\left(\mathrm{tCO}_{2} / \mathrm{t}\right), \mathrm{D}=$ distance of transportation $(\mathrm{km}), \mathrm{Q}=$ Quantity of material (tonnes), $\alpha=$ Fuel consumption of rigid $\mathrm{HGV}$ and $\beta=\mathrm{CO}_{2}$ emissions per litre of fuel.

The study by Raja et al (2015) provided data for a range of products with varying masses. This allowed the overall energy consumption per $\mathrm{kg}$ of product produced to be calculated. In order to present these results in the form of EC, the energy consumed had to be converted to EC values using appropriate $\mathrm{CO}_{2}$ emissions factors. This was achieved by converting using Equation 27.2 the energy measurements made on the production lines using factors for UK electricity of $0.44548 \mathrm{kgCO}_{2} \mathrm{e} / \mathrm{kWh}$ and gas $0.18404 \mathrm{kgCO}_{2} \mathrm{e} / \mathrm{kWh}$ (DEFRA, 2013). These conversion factors represent the direct emissions at the point of use of the fuel or generation of electricity. They do not account for indirect emissions associated with factors such as extraction of the gas; setting up of a power plant etc. The factors are susceptible to change and can vary worldwide. For instance a country employing more renewable energy sources would subsequently produce less $\mathrm{CO}_{2}$ per unit of energy.

$$
E \times \alpha=C \quad \text { (Equation 27.2) }
$$

Where $\mathrm{E}=$ Energy consumed $(\mathrm{kWh} / \mathrm{t}), \alpha=$ Conversion Factor $\left(\mathrm{tCO}_{2} / \mathrm{kWh}\right)$ and $\mathrm{C}=$ Embodied Carbon $\left(\mathrm{tCO}_{2}\right)$

A comparison of the EC values for product lines and a full discussion of the method of measurement are presented by Raja et al (2015). The small difference in EC values (Table 27.2) can be attributed to different manufacturing processes and fuel sources. One manufactured geotextile using a combination of electricity and gas and employed both needle-punching and thermal bonding techniques, and the other used only electricity and needle punching. In the case study reported by Raja et al (2015) the mean value for non-woven geotextiles was $2.35 \mathrm{tCO}_{2} \mathrm{e} / \mathrm{t}$. These results do not imply that a thermally bonded material is "more sustainable" than a needle punched material, simply that in this case one material had slightly higher embodied carbon than the other. 


\section{Table 27.2 Embodied Carbon values for geotextiles (after Raja et al, 2015)}

Additional data on the EC of geotextile products, and all geosynthetic materials, is required to further develop a database of geosynthetic embodied carbon for use in carbon footprinting studies. The work by Raja et al (2015) and others should not be interpreted to mean that the EC values available in commonly used databases are inaccurate as the values included in these for plastic materials are not direct comparisons. They are values for different forms of materials whether granulate or in the case of polypropylene, injection moulding or orientated film. Due to a lack of specific embodied carbon values for geosynthetics in general and geotextiles in particular, to date these values have commonly been employed as alternatives. However, the values reported by Raja et al (2015) can now be used for future carbon footprinting and these will aid more rigorous assessments of construction solution options.

The study by Raja et al (2015) highlights the significance of weight of a geosynthetic material. Whilst there has been significant debate around the relevance of weight as a performance characteristic, in sustainability terms the weight of the geotextile is significant, as the embodied carbon of the raw polymer accounts for approximately $80 \%$ of the final EC for a geosynthetic product at the gate. Therefore, in order to achieve the optimum sustainability from a geosynthetic based construction solution, the geosynthetics must be used appropriately in design and also the polymer used efficiently in producing a material that can achieve the design criteria.

\subsection{Sustainable Construction Assessment}

The use of environmental and sustainability based assessment methods and rating systems is an important factor in driving sustainable construction. The methods most commonly employed in the UK include the Building Research Establishment's Environmental Assessment Method (BREEAM) (BRE, 2011) and CEEQUAL. (2012). Leadership in Energy and Environmental Design (LEED, 2015) is the United States equivalent rating system for "green" buildings. These systems are being used to raise awareness of sustainability through improved project specification, design and construction of buildings and civil engineering works.

In the geosynthetic industry, some manufacturers have developed simple carbon calculators that can be used to show the possible carbon emission savings between employing their product and a nongeosynthetic solution. These can be used by designers and clients to gain a quick understanding of the sustainable benefits of employing a geosynthetic based solution. However their simplicity and ease of use also mean that these in house calculators can lack credibility and accuracy and they will be seen by some as simple promotional tools. It can be argued that there is a need for an industry standard carbon calculator or methodology, one that is backed and endorsed by a number of geosynthetic manufacturers and suppliers, and recognised and trusted by construction organisations and clients.

\subsection{Life Cycle Boundaries}

Life cycle analysis (LCA) is a technique employed to assess the environmental impacts of products, buildings or other services throughout their life-cycle (Menzies, 2007). In order to carry out an analysis, clearly defined boundary conditions are required to describe which parts of the material 
production, manufacture and deployment are taken into account during an LCA analysis. Figure 27.1 defines four commonly used LCA boundaries:

Cradle-gate: This considers all of the emissions in the extraction and manufacture of a product, including all transport related emissions associated with interim stages of manufacture (such as moving of polymer fibres and granules);

Cradle-site: In addition to cradle-gate, this includes transportation of material to the site. This must include the cumulative emissions from all transportation types (e.g. road, rail, ship);

Cradle to end of construction: In addition to cradle- site this includes all of the emissions associated with the construction process. For geotextiles this may include items such as the preparation of the subgrade by rollers, excavators used to lift rolls of material, excavation and filling. Items such as provision of cabins and welfare facilities should also be considered as these have an associated embodied carbon for the construction phase.

Cradle-grave: In addition to cradle to end of construction this includes the demolition and disposal emissions associated with the end of life of a structure.

Figure 27.1 System boundaries and stages of LCA

In order to carry out a rigorous LCA, the boundaries must be fit for purpose for the intended comparison and, importantly, must be clearly defined. When carrying out comparisons of alternative materials and systems, elements common to both solutions may be excluded, as emissions would be identical for this component of the works. An example of this would include site mobilisation, preparatory clearance works or provision of welfare. Where such omissions are made, these should be clearly stated in the LCA assumptions to avoid misinterpretation of the reported emissions of an engineered solution.

Plastics are typically high EC materials as shown in Table 27.1 (Hammond and Jones, 2011; Ecolnvent Centre, 2013), however, when used correctly and efficiently, a geosynthetic based construction solution can have significantly lower EC than alternative solutions. The study by WRAP (2010) highlighted lower transportation emissions as a key advantage of geosynthetics due to their comparatively low weight and volume compared to carrying soil or aggregate to site, and therefore transportation phases must be within LCA boundaries used. Where site won materials can be incorporated into the design this will produce a lower EC solution by reducing the need to import and/or export material from site. However, where the properties of these site won materials are marginal for the applications required (e.g. low strength), geosynthetics may be used to improve the properties of these material to allow their use and hence to achieve both cost and EC savings.

\subsection{Framework and calculation methods for project carbon footprinting}

To ensure the accuracy and impact of the case studies that compare EC of geosynthetic based and alternative construction solutions requires a robust $\mathrm{CO}_{2}$ calculation framework. This ensures the validity and credibility of the results by comparing like for like activities with respect to $\mathrm{CO}_{2}$ emissions generated. Figure 27.2 details the framework for a $\mathrm{CO}_{2}$ assessment of a construction solution 
incorporating geosynthetics. The framework comprises five stages of analysis, however, depending on the LCA boundaries, Stages 4 and 5 may be omitted:

- Stage 1 involves setting the LCA boundary conditions, and scope of the $\mathrm{CO}_{2}$ analysis.

- For Stage 2 the project must be defined, and geosynthetic and alternative design solutions developed. This may involve conceptual or detailed design of both the geosynthetic and alternative systems, depending on the rigour required within the analysis. In Stage 2, where multiple solutions are being analysed, any common activities to all solutions may be omitted to simplify the analysis.

- For Stage 3 the material quantities must be determined and embodied energy / embodied carbon values must be sourced for each material. The values adopted, and importantly the source data, must be recorded to ensure transparency and ease of comparison. The end of Stage 3 will give cradle-gate emissions for the component parts of the construction solutions.

- Stage 4 progresses the analysis to consider the cradle-site LCA boundary, and therefore includes emissions associated with transporting material to the site. The quantities of material, haulage methods, fuel usage and emission factors to convert fuel usage into $\mathrm{CO}_{2}$ emissions are require. Where a comparison of two or more solutions is being carried out, the analyst may again opt to omit any activities common to all solutions.

- Stage 5 progresses the analysis to consider the cradle-end of construction LCA boundary. To achieve this, the analyst must consider the type of plant used in construction, associated fuel usage and emission factors to quantify the emissions in construction. Again, activities common to alternative solutions may be omitted from the calculations.

Figure $27.2 \mathrm{CO}_{2}$ calculation framework

\subsection{Example Projects}

\subsubsection{Introduction}

Three construction case studies are detailed below, with EC values calculated for geotextile based and alternative solutions. Calculation examples 1 and 2 compare EC for geosynthetic and alternative construction solutions for protection and working platform applications respectively, using a $1 \mathrm{~m}^{2}$ plan area unit of materials for cradle to site LCA boundary conditions. The influence of haulage distance for mineral components on total EC values is also considered in calculation example 1. Example 3 compares EC for geosynthetic and soil based landfill capping solutions. The LCA boundary of cradle to end of construction is defined and a unit area of 1 ha area is considered to enable EC from construction activities to be meaningfully included.

\subsubsection{Calculation Example 1: Protection Application}

LCA Boundary: Cradle-Site

Geosynthetic Solution: Non-woven geotextile

Non-geosynthetic Solution: $100 \mathrm{~mm}$ layer of selected non-cohesive soils

The first example considers $1 \mathrm{~m}^{2}$ of a simple single layer protection layer of either sand or a nonwoven geotextile. Table 27.3 gives the input parameters required for the analysis. The cradle-gate 
embodied $\mathrm{CO}_{2}$ emissions for the soil solution are derived from Inventory of (Embodied) Carbon \& Energy (ICE) v2.0 (Hammond and Jones, 2011) and the geotextile values are from Raja et al (2015). The transport emissions are calculated using equation 27.1, assuming that each truckload is a full load. The purpose of this example is to demonstrate comparison of $\mathrm{CO}_{2}$ and is not intended as a detailed comparison of the equivalence of the geosynthetic and soil solutions. The selected geotextile material is typical of that used in waste capping applications, and should protection from greater loads be required, the geotextile grade may alter.

\section{Table 27.3 Example 1 - Input values for protection $\mathrm{CO}_{2}$ comparison.}

The outputs from the analysis are presented in Table 27.4. The results show that the cradle-to-gate emissions are $18 \%$ higher for the geosynthetic solution. When developing the comparison to include the transport element (i.e. the cradle-site LCA boundary), the geosynthetic EC is not sensitive to transportation distances and the cradle to-gate emissions are dominant. However, the soil solution is sensitive to transport distance. For haulage distances greater than $12 \mathrm{~km}$ the geosynthetic solution is shown to have lower cradle-site EC than the soil solution. Figure 27.3 shows the relationship between haulage distance and EC (cradle-site).

Table 27.4 Example 1 - Calculated EC values for geosynthetic and soil protection solutions

Figure 27.3 Example 1 - Transport Distance vs Embodied Carbon for cradle-site construction solutions.

This example highlights the importance of considering each project on a case by case basis, and shows that one solution cannot simply be classed as more sustainable than another. Even taking this very simple comparison of alternative materials, the sensitivity of the comparison to haulage distance will result in a different outcome for sustainability calculations depending on the locality of the site.

\subsubsection{Calculation Example 2: Working platform}

LCA Boundary: Cradle-Site

Non-Geosynthetic Solution: $1.2 \mathrm{~m}$ thickness of selected coarse aggregate

Geosynthetic Solution: $0.6 \mathrm{~m}$ thickness of selected coarse aggregate and a reinforcing geosynthetic (i.e. geotextile) layer (see Figure 27.4)

\section{Figure 27.4 Example 2 - Schematic of the geosynthetic and alternative working platforms}

This example considers a comparison of a plan area of $1 \mathrm{~m}^{2}$ of working platform. Two solutions are considered; one with geosynthetic reinforcement, the other without. The calculations are for a working platform to support $1160 \mathrm{kN}$ from a Piling Rig (SoilMec CM120) mast foot pad. Assuming Terzaghi's bearing capacity equation gives a load spread of 45 degrees, a reduction in soil thickness of $50 \%$ can be realised with a layer of geosynthetic reinforcement. Again the purpose of this example is to carry out an EC comparision of the two solutions and is based on an example calculation carried out for a site. Should the loadings, subgrade, aggregate or calculation methods differ; the embodied calculated EC will also change. This highlights the importance of considering each project on a case by case basis. 
A $500 \mathrm{~g} / \mathrm{m}^{2}$ polyester woven geotextile is assumed for the reinforcing layer. This calculation example also highlights the challenge of selecting an appropriate EC value for the geotextile. WRAP (2010) sourced polyester geogrid data informed by the ICE database v1.6 (Hammond \& Jones, 2008), however, with no stated value for polyester one for general polyethylene of $1.94 \mathrm{tCO}_{2} \mathrm{e} / \mathrm{t}$ was employed. Raja et al (2015) calculated EC for a polyester geogrid of $2.36 \mathrm{tCO} e / t$. However, there is no data available for woven polyester geotextile. For the purpose of this calculation the higher value of $2.36 \mathrm{tCO} e / \mathrm{t}$ is adopted, however, the potential source of error in calculations must be acknowledged. The input parameters are shown in Table 27.5.

\section{Table 27.5 Example 2 - Input values for working platform $\mathrm{CO}_{2}$ comparison}

The calculated EC values for the two working platform solutions are presented in Table 27.6. The $50 \%$ reduction in aggregate gives a $6.00 \mathrm{kgCO}_{2}$ reduction in $\mathrm{EC}$ per $\mathrm{m}^{2}$ of working platform. There is an additional saving of $2.34 \mathrm{kgCO}_{2}$ from transport emissions, however, as seen in example 1 (Section 27.11.2) this is sensitive to distance from the site. The EC of the geosynthetic component is 1.19 $\mathrm{kgCO}_{2}$. Overall a $43 \% \mathrm{EC}$ reduction is calculated using the geosynthetic solution.

\section{Table 27.6 Example 2 - Calculated EC values for working platform $\mathrm{CO}_{2}$ comparison}

The EC of the geosynthetic component in this example would have been reduced from $1.19 \mathrm{kgCO}_{2}$ to $0.98 \mathrm{kgCO}_{2}$ if the lower value of $1.94 \mathrm{tCO}_{2} \mathrm{e} / \mathrm{t}$ was employed as in the WRAP (2010) studies. For this example the savings are less dependent on the $\mathrm{EC}$ of the geosynthetic component as the aggregate EC dominates the overall EC values.

\subsubsection{Calculation Example 3: Landfill Capping Solution}

LCA Boundary: Cradle-End of Construction

Non-geosynthetic Solution: $1000 \mathrm{~mm}$ compacted cohesive soils

Geosynthetic Solution: $1 \mathrm{~mm}$ LLDPE geomembrane and a non-woven geotextile (see Figure 27.5)

This example considers a geosynthetic and non-geosynthetic capping system for the cradle to end-ofconstruction LCA boundary. The calculations adopt the framework set out earlier in this chapter. Note for this example a 1 ha area is considered. The input values for the comparison are presented in Table 27.7. Raja et al (2014) considered a similar calculation example and found the EC values in the ICE database (Hammond and Jones, 2011) for Clay materials to overestimate the emissions, therefore a value of $0.0003 \mathrm{kgCO}_{2} \mathrm{e} / \mathrm{kg}$ has been adopted for cover clay in this study.

\section{Figure 27.5 Example 3 - Schematic of the geosynthetic and alternative capping systems}

\section{Table 27.7 Example 3 - Input values for landfill capping $\mathrm{CO}_{2}$ comparison}

In order that the calculations achieve the cradle-end-of-construction LCA boundary conditions specified they first account for the production and transport of material as in examples 1 (Section 27.11.2) and 2 (Section27.11.3). The construction emissions in this case account for the main carbon producing aspects of the construction. In the case of the clay this is dominated by the compaction of the soil by vibratory roller. For the geomembrane, the calculations consider the preparation of the subgrade by vibratory roller and the welding of the cap cover seams. Elements common to both solutions, such as waste re-grading, the placement of restoration soils and establishment of welfare 
facilities, are omitted from the comparison. Therefore, it should be noted that the total $\mathrm{CO}_{2}$ emissions are for comparative purposes and not the total emissions of the project. The activities accounted for in this case are not exhaustive, and a more rigorous study may include lifting the geosynthetic into place, moving clay on site with a bulldozer and even personnel related emissions.

\section{Embodied Carbon}

The calculated embodied carbon values for the landfill capping example are presented in Table 27.8. The embodied carbon of the geosynthetic solution is significantly higher than that for the site won clay, thus a cradle-gate-comparison would show the clay soil solution to be more sustainable.

\section{Table 27.8 Example 3 - Calculated EC values for landfill capping $\mathrm{CO}_{2}$ comparison}

\section{Transport}

Table 27.9 shows the calculated transport emission values for the landfill capping calculation example. A distance of $20 \mathrm{~km}$ is assumed, however, the transport emission value is linearly proportional to haulage distance allowing parametric sensitivity study for distance to easily be determined as in example 1 (Section 27.11.2). The volume and mass of the clay results in 1000 vehicle movements to achieve the required clay placement, compared to a single delivery of geosynthetic material. Clearly there are also social implications associated with additional traffic, in addition to comparing $\mathrm{CO}_{2}$ emissions.

Table 27.9 Example 3 - Calculated transport emissions values for landfill capping $\mathrm{CO}_{2}$ comparison

\section{Construction}

Table 27.10 shows the calculated construction emission values for the landfill capping example. The clay compaction emits $9.98 \mathrm{tCO}_{2} \mathrm{e}$. For the geomembrane the welding emissions are comparatively small, $0.03 \mathrm{tCO}_{2} \mathrm{e}$, and the subgrade preparation emissions are calculated to be $0.42 \mathrm{tCO}_{2} \mathrm{e}$.

\section{Table 27.10 Example 3 - Construction emissions for landfill capping $\mathrm{CO}_{2}$ comparison}

\section{Total Emissions}

The overall emissions for the geosynthetic and soil solutions are given in Table 27.11. The calculated emissions for the clay solution are $47 \%$ higher than for the geosynthetic solution, for a $20 \mathrm{~km}$ clay haul distance, despite the fact that the cradle-gate comparison showed the geosynthetic emissions to be over $500 \%$ higher than the clay. This highlights the importance of comparing the EC for the whole construction solution and not simply the component products. It should be noted that if the clay is local to the works and haulage distances can be reduced, the clay emissions will also be significantly reduced as demonstrated by example 1 (Section 27.11.2). Therefore, a site by site comparison is advised.

Table 27.11 Example 3 - Calculated embodied carbon emissions for the geosynthetic and clay landfill capping solutions

\subsection{Summary}

Demonstrating the sustainability of construction solutions is becoming an increasingly important aspect of design. While there are many criteria that can be used to assess sustainability, it is accepted practice to use carbon emissions in both setting policy (e.g. the Kyoto Protocol (United 
Nations, 1998)) and practice (e.g. WRAP, 2010)). Numerous countries world-wide have set targets for reducing carbon emissions and these are impacting on construction practice. Published studies have demonstrated that solutions incorporating geosynthetics are often more sustainable, as measured by carbon emissions, than alternative, often termed traditional, solutions. Carbon footprinting techniques are used to establish the embodied carbon for a solution over set life cycle boundaries. A key component of any such assessment is the embodied carbon of the materials used. Generic values for plastics are published in construction materials databases but it is only recently that geosynthetic specific values have been published. EC values for geotextile products have been reported by Raja et al (2015). Example calculations have been presented for defined construction units of three common design solutions incorporating geotextiles. These demonstrate the methodology of calculation and the importance of factors such as: defining the LCA boundaries (i.e. cradle to end of construction), the selection of EC values for materials, and the critical role of transport related carbon emissions. The framework outlined can be used to undertake site specific calculations and these inform decisions on selection of construction approaches that contribute to sustainable practice.

\section{References}

BRE (2008). BREEAM Manual. BRE, Garston, Watford.

BRE (2011). BREEAM New Construction- Non Domestic Building. Technical Manual SD5073- 2.0:2011, UK.

Brundtland, G. (1987). Our common future: The World Commission on Environment and Development. Oxford University Press, Oxford, UK.

CEEQUAL (2012). Assessment Manual for UK \& Ireland Projects. Version 5.0, UK.

DEFRA (2013). Guidelines to Defra's GHG conversion factors for company reporting. Department for Environment, Food and Rural Affairs, London, UK.

Department for Transport 2012. Fuel consumption by HGV vehicle type in Great Britain, 1993 to 2010. Table RFS0141. Domestic road freight activity (RFS01). See https://www.gov.uk/government/statistical-data-sets/rfs01-goods-lifted-and-distance-hauled [Accessed on 25th Jan 2014]

Ecolnvent Centre (2010). Ecolnvent data v2.2. Ecoinvent reports No. 1-25, Swiss Centre for Life Cycle Inventories, Duebendorf, Switzerland.

Ecolnvent Centre (2013). Ecolnvent data v3.0. Ecoinvent reports No. 1-25, Swiss Centre for Life Cycle Inventories, Duebendorf, Switzerland.

EPA (2006). "Life Cycle Assessment: Principles and Practice. EPA/600/R-06/060. produced by Scientific Applications Internal Corporation. May 2006.

EPA (2014). Causes of Climate Change. United States Environmental Protection Agency. See http://www.epa.gov/climatechange/science/causes.html [accessed on 21/11/2014]

European Union (2013). The EU Emissions Trading System (EU ETS). 
Hammond, G.P. and Jones, C.I. (2008). Inventory of (Embodied) Carbon \& Energy (ICE) v1.6

Hammond, G.P. and Jones, C.I. (2011). Inventory of (Embodied) Carbon \& Energy (ICE) v2.0

Heerten, G. (2012). Reduction of climate-damaging gases in geotechnical engineering practice using geosynthetics. Geotextiles and Geomembranes, 30: 43-49.

IPCC (2014). Inter-governmental Panel on Climate Change- Organization. See http://www.ipcc.ch/organization/organization.shtml (accessed 05/12/2014).

LEED (2015). Green Building Training. See http://www.greenbuilding-training.com/?gclid=CLmhveSUMUCFWXLtAodsWwAsg (accessed 05/6/2015)

Menzies, G.F., Turan, S. \& Banfill, P.F.G. (2007). Life-cycle assessment and embodied energy: A review. Proceedings of the ICE - Construction Materials, 160(4), 135-143

Raja, J., Dixon, N., Fowmes, G., Frost, M.W. \& Assinder, P. (2014). Comparison of carbon dioxide emissions for two landfill capping. Proceedings of the ICE - Engineering Sustainability, Volume 167, Issue 5, $197-207$.

Raja, J., Dixon, N., Fowmes, G., Frost, M.W. \& Assinder, P. (2015). Sustainable Construction Solutions Using Geosynthetics: Obtaining Reliable Embodied Carbon Values. Geosynthetics International (Accepted for publication)

Stucki, M., Büsser, S., Itten, R., Frischknecht, R. \& Wallbaum, H. (2011). Comparative Life Cycle Assessment of Geosynthetics versus Conventional Construction Materials. European Association of Geosynthetic Manufacturers (EAGM), Switzerland.

TSO (The Stationary Office) (2008). Climate Change Act 2008: Elizabeth II. Chapter 27. 2008, London, TSO

United Nations (1992). United Nations Framework Convention on Climate Change. S. Treaty Doc No. 102-38, 1771 U.N.T.S. 107

United Nations (1998). Kyoto Protocol to the United Nations Framework Convention on Climate Change. U.N. Doc FCCC/CP/1997/7/Add.1, 37 I.L.M. 22.

WRAP (2010). Sustainable Geosystems in Civil Engineering Applications. Waste and Resources Action Programme, Banbury, UK, Project MRF116.

WRI (World Resources Institute) (2014). Climate Analysis Indicators Tool (CAIT) 2.0: WRI's climate data explorer. Accessed November 2014. http://cait.wri.org. 


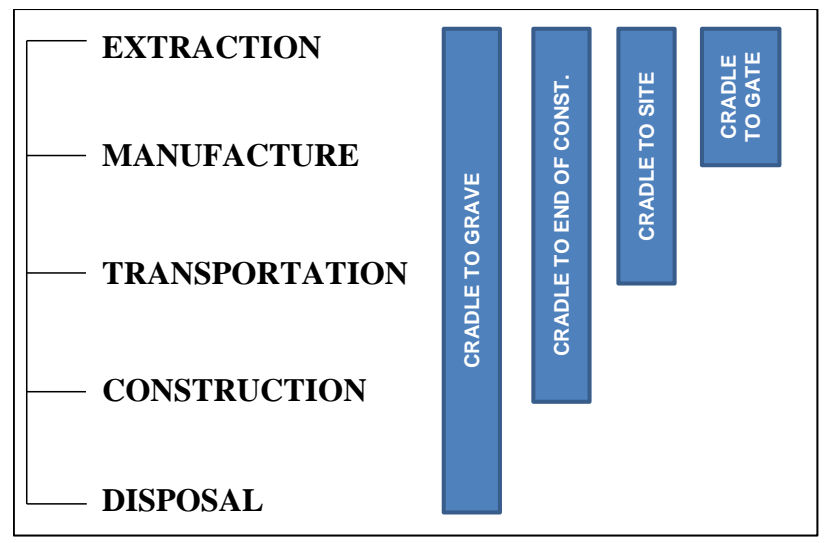

Figure 27.1 System boundaries and stages of LCA 


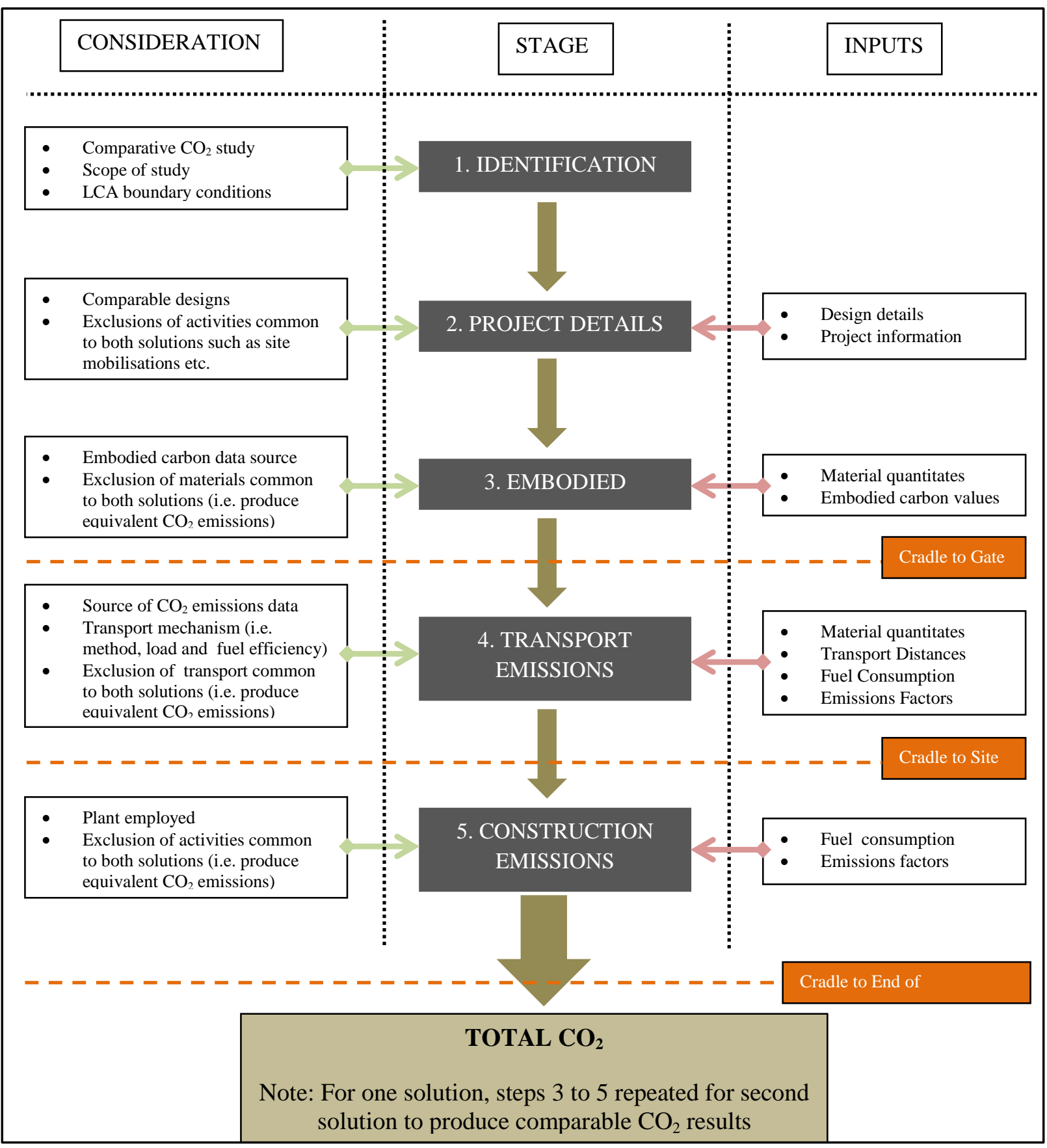

Figure $27.2 \mathrm{CO}_{2}$ calculation framework 


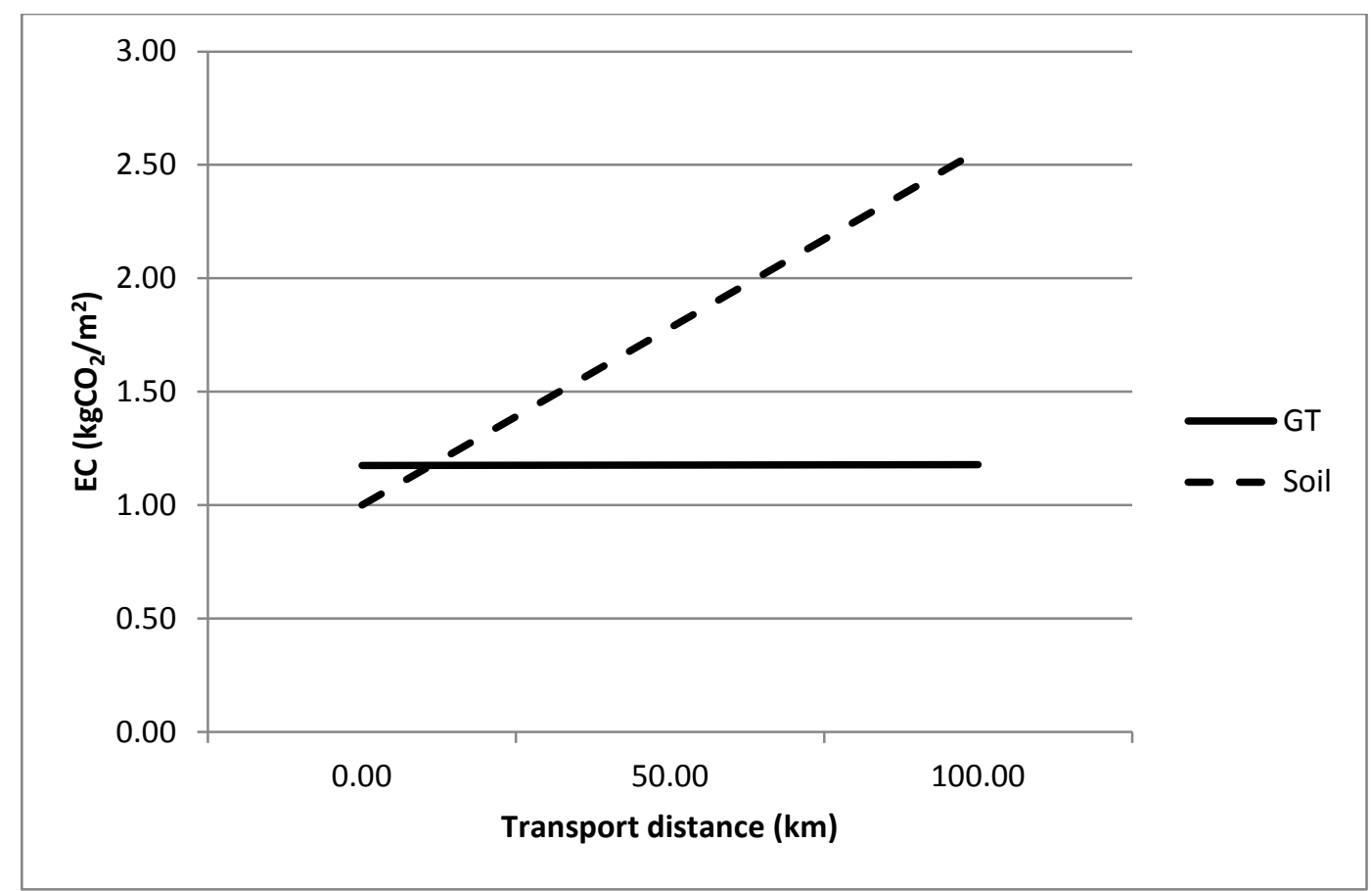

Figure 27.3 Example 1 - Transport Distance vs Embodied Carbon for cradle-site construction solutions

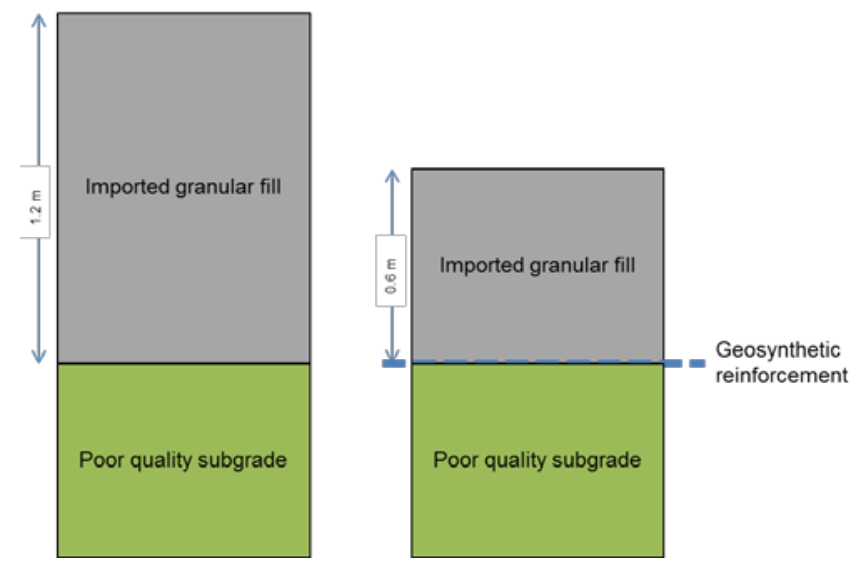

Figure 27.4 Example 2 - Schematic of the geosynthetic and alternative working platforms 
LLDPE geomembrane

with protective geotextile

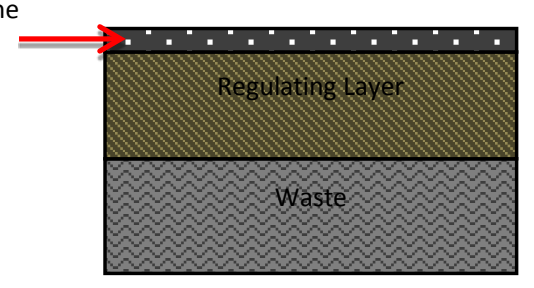

a) Design that employs a $1 \mathrm{~mm}$ LLDPE geomembrane and a non-woven geotextile

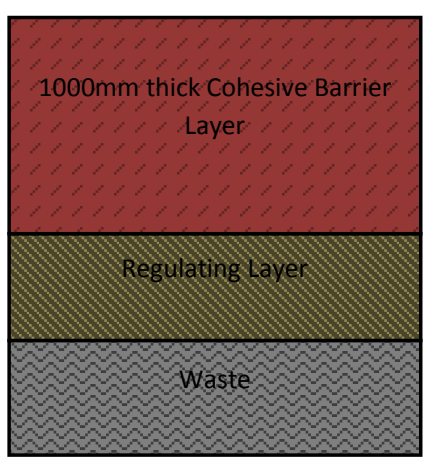

b) Alternative design that could be employed involving a $1 \mathrm{~m}$ thick cohesive soil layer, to replace the two geosynthetic layers

Figure 27.5 Example 3 - Schematic of the geosynthetic and alternative capping systems 
Table 27.1 Embodied carbon values for different plastics from ICE (Hammond \& Jones, 2011) and Ecolnvent v2.2 (Ecolnvent Centre, 2010)

\begin{tabular}{|c|c|c|}
\cline { 2 - 3 } \multicolumn{1}{c|}{} & \multicolumn{2}{c|}{ Embodied Carbon (kg CO$\left.{ }_{2} \mathbf{e} / \mathrm{Kg}\right)$} \\
\hline Material & ICE v2.0, 2011 & $\begin{array}{c}\text { Ecolnvent v2.2, } \\
\mathbf{2 0 1 0}\end{array}$ \\
\hline General Plastic & 3.31 & - \\
\hline High Density Polyethylene (HDPE) & 1.93 & - \\
\hline HDPE Pipe & 2.52 & - \\
\hline Low Density Polyethylene (LDPE) & 2.08 & 2.06 \\
\hline LDPE Film & 2.60 & 2.66 \\
\hline Polypropylene, Orientated Film & 3.43 & - \\
\hline Polypropylene, Injection Moulding & 4.49 & - \\
\hline Polypropylene, Granules & - & 1.98 \\
\hline Polyester, Granules & - & 2.70 \\
\hline Polyester, Granules - bottle grade & - & 2.90 \\
\hline
\end{tabular}

Table 27.2 Embodied Carbon values for geotextiles (after Raja et al, 2015)

\begin{tabular}{|c|c|c|c|c|}
\hline $\begin{array}{c}\text { Geotextile } \\
\text { Type }\end{array}$ & $\begin{array}{c}\text { Polymer } \\
\text { embodied } \\
\text { carbon } \\
\left(t C \mathrm{CO}_{2} e / t\right)\end{array}$ & $\begin{array}{c}\text { Conversion of } \\
\text { Granules to } \\
\text { fibres } \\
\left(t C \mathrm{C}_{2} e / t\right)\end{array}$ & $\begin{array}{c}\text { Manufacturing } \\
\text { Carbon } \\
\text { emissions } \\
\left(t C \mathrm{CO}_{2} e / t\right)\end{array}$ & $\begin{array}{c}\text { Total } \\
\text { Embodied } \\
\text { Carbon } \\
\left(t C \mathrm{O}_{2} e / t\right)\end{array}$ \\
\hline $\begin{array}{c}\text { Non-woven } \\
\text { Needle punched }\end{array}$ & \multirow{2}{*}{1.983} & 0.241 & 0.053 & 2.28 \\
\hline $\begin{array}{c}\text { Non-woven } \\
\text { Thermally } \\
\text { Bonded/Needle } \\
\text { Punched }\end{array}$ & & 0.189 & 2.42 \\
\hline
\end{tabular}


Table 27.3 Example 1 - Input values for protection $\mathrm{CO}_{2}$ comparison.

\begin{tabular}{|l|l|l|}
\hline Property & Value & Units \\
\hline $\begin{array}{l}\text { Geotextile cradle to gate EC value (Raja et al } \\
2015)\end{array}$ & 2.35 & $\mathrm{kgCO}_{2} \mathrm{e} / \mathrm{kg}$ \\
\hline $\begin{array}{l}\text { Sand cradle to gate EC value (Hammond and } \\
\text { Jones, 2011) }\end{array}$ & 0.005 & $\mathrm{kgCO}_{2} \mathrm{e} / \mathrm{kg}$ \\
\hline Transport Distance & 1 to 100 & $\mathrm{~km}$ \\
\hline Density of selected non-cohesive soil & 2000 & $\mathrm{~kg} / \mathrm{m}^{3}$ \\
\hline$\alpha=$ Fuel consumption of rigid HGV & 3.33 & $\mathrm{~km} / \mathrm{l}$ \\
\hline$\beta=\mathrm{CO}_{2}$ emissions per litre of fuel & 2.60 & $\mathrm{kgCO}_{2} /$ litre \\
\hline
\end{tabular}

Table 27.4 Example 1- Calculated EC values for geosynthetic and soil protection solutions

\begin{tabular}{|l|c|c|c|}
\hline & \multicolumn{3}{|c|}{} \\
\hline Haulage distance & $1 \mathrm{~km}$ & $50 \mathrm{~km}$ & $100 \mathrm{~km}$ \\
\hline Embodied & \multicolumn{3}{|c|}{ Embodied Carbon per metre square (kgCO $\left.\mathbf{~}^{2} / \mathbf{m}^{2}\right)$} \\
\hline Soil solution & \multicolumn{3}{|c|}{1.00} \\
\hline Geosynthetic Solution & \multicolumn{3}{|c|}{1.18} \\
\hline Transport & 0.02 & 0.78 & 1.56 \\
\hline Soil solution & 0.00004 & 0.002 & 0.004 \\
\hline Geosynthetic Solution & & & 2.56 \\
\hline Total & 1.02 & 1.78 & 1.18 \\
\hline Soil solution & 1.18 & 1.18 & \\
\hline Geosynthetic Solution & & & \\
\hline
\end{tabular}

Table 27.5 Example 2 - Input values for working platform $\mathrm{CO}_{2}$ comparison

\begin{tabular}{|l|l|l|}
\hline Property & Value & Units \\
\hline $\begin{array}{l}\text { Polyester geosynthetic cradle to gate EC value } \\
\text { (Raja et al 2015) }\end{array}$ & 2.36 & $\mathrm{kgCO}_{2} \mathrm{e} / \mathrm{kg}$ \\
\hline $\begin{array}{l}\text { Aggregate cradle to gate EC value (Hammond } \\
\text { and Jones, 2011) }\end{array}$ & 0.005 & $\mathrm{kgCO}_{2} \mathrm{e} / \mathrm{kg}$ \\
\hline Geotextile Transport Distance & 200 & $\mathrm{~km}$ \\
\hline Aggregate Transport Distance & 25 & $\mathrm{~km}$ \\
\hline Unit weight of selected non-cohesive soils & 2000 & $\mathrm{~kg} / \mathrm{m}^{3}$ \\
\hline$\alpha=$ Fuel consumption of rigid HGV & 3.33 & $\mathrm{~km} / \mathrm{l}$ \\
\hline$\beta=\mathrm{CO}_{2}$ emissions per litre of fuel & 2.60 & $\mathrm{kgCO}_{2} / \mathrm{litre}$ \\
\hline
\end{tabular}


Table 27.6 Example 2 - Calculated EC values for working platform $\mathrm{CO}_{2}$ comparison

\begin{tabular}{|l|c|c|}
\hline & $\begin{array}{c}1.2 m \\
\text { Aggregate, EC } \\
\left(\mathbf{k g C O}_{2} \mathrm{e}\right)\end{array}$ & $\begin{array}{c}\mathbf{0 . 6 m} \text { Aggregate + Geotextile } \\
\text { Reinforcement, EC }\left(\mathbf{k g C O}_{2} \mathrm{e}\right)\end{array}$ \\
\hline Aggregate EC (cradle-gate) & 12.00 & 6.00 \\
\hline Aggregate Transport & 4.68 & 2.34 \\
\hline Total Aggregate EC (cradle-site) & $\mathbf{1 2 . 0 0}$ & $\mathbf{8 . 3 4}$ \\
\hline & & 1.18 \\
\hline Geosynthetic EC (cradle-gate) & - & 0.008 \\
\hline Geosynthetic Transport & - & $\mathbf{1 . 1 9}$ \\
\hline Total Transport & $\mathbf{4 . 6 8}$ & $\mathbf{9 . 5 3}$ \\
\hline & &
\end{tabular}

Table 27.7 Example 3 - Input values for landfill capping $\mathrm{CO}_{2}$ comparison

\begin{tabular}{|c|c|c|}
\hline Property & Value & Units \\
\hline \multicolumn{3}{|l|}{ Input data for Cradle to Gate } \\
\hline Area & 10,000 & $\mathrm{~m}^{2}$ \\
\hline Geomembrane mass per unit area & 0.939 & $\mathrm{~kg} / \mathrm{m}^{2}$ \\
\hline Geotextile mass per unit area & 0.500 & $\mathrm{~kg} / \mathrm{m}^{2}$ \\
\hline Geotextile cradle to gate EC value (Raja 2015) & 2.35 & $\mathrm{kgCO}_{2} \mathrm{e} / \mathrm{kg}$ \\
\hline $\begin{array}{l}\text { Geomembrane cradle to gate EC value (based on } \\
\text { Hammond and Jones, 2011) }\end{array}$ & 2.08 & $\mathrm{kgCO}_{2} \mathrm{e} / \mathrm{kg}$ \\
\hline Clay cradle to gate EC value (Raja et al 2014) & 0.0003 & $\mathrm{kgCO}_{2} \mathrm{e} / \mathrm{kg}$ \\
\hline Density of selected non-cohesive soils & 2000 & $\mathrm{~kg} / \mathrm{m}^{3}$ \\
\hline \multicolumn{3}{|l|}{ Additional Data for cradle-site } \\
\hline Geotextile Transport Distance & 200 & $\mathrm{~km}$ \\
\hline Clay Transport Distance & 10 & $\mathrm{~km}$ \\
\hline$\alpha=$ Fuel consumption of rigid HGV & 3.33 & $\mathrm{~km} / \mathrm{l}$ \\
\hline$\beta=\mathrm{CO}_{2}$ emissions per litre of fuel & 2.60 & $\mathrm{kgCO}_{2} /$ litre \\
\hline \multicolumn{3}{|c|}{ Additional Data for cradle-end-of-construction } \\
\hline Clay Layer thickness & 250 & $\mathrm{~mm}$ \\
\hline Compaction effort & 1000 & $\mathrm{~m}^{2} /$ hour \\
\hline Compaction Plant Fuel Usage & 16.0 & litres / Hr \\
\hline$\beta=\mathrm{CO}_{2}$ emissions per litre of fuel & 2.60 & $\mathrm{kgCO}_{2} /$ litre \\
\hline Wattage of welding equipment & 1.8 & $\mathrm{~kW}$ \\
\hline Length of welds & 2200 & $\mathrm{M}$ \\
\hline Welding speed & 2.5 & $\mathrm{~m} / \mathrm{min}$ \\
\hline
\end{tabular}


Table 27.8 Example 3 - Calculated EC values for landfill capping $\mathrm{CO}_{2}$ comparison

\begin{tabular}{|l|l|l|l|l|l|}
\hline Geomembrane mass & 9.39 & $\mathrm{t}$ & Clay mass & 20000 & $\mathrm{t}$ \\
\hline Geotextile mass & 5 & $\mathrm{t}$ & & & \\
\hline Geotextile embodied & 19.5312 & $\mathrm{t}$ & & & \\
\hline Geotextile embodied & 11.75 & $\mathrm{t}$ & & & \\
\hline $\begin{array}{l}\text { Geosynthetics Total } \\
\text { Embodied }\end{array}$ & 31.2812 & $\mathrm{tCO}_{2} \mathrm{e}$ & Clay Total Embodied & 6 & $\mathrm{tCO}_{2} \mathrm{e}$ \\
\hline
\end{tabular}

Table 27.9 Example 3 - Calculated transport emissions values for landfill capping $\mathrm{CO}_{2}$ comparison

\begin{tabular}{|l|l|l|l|l|l|}
\hline Distance & 200.00 & $\mathrm{~km}$ & Distance & 20.00 & $\mathrm{~km}$ \\
\hline Truckloads & 1.00 & & Truckloads & 1000.00 & \\
\hline $\begin{array}{l}\text { Geosynthetic transport } \\
\text { emissions }\end{array}$ & 0.31 & $\mathrm{tCO}_{2} \mathrm{e}$ & Clay transport emissions & 31.23 & $\mathrm{tCO}_{2} \mathrm{e}$ \\
\hline
\end{tabular}

Table 27.10 Example 3 - Construction emissions for landfill capping $\mathrm{CO}_{2}$ comparison

\begin{tabular}{|c|c|c|c|c|c|}
\hline Number of layers & 4.00 & & Seam length (measured) & 2200.00 & $\mathrm{~m}$ \\
\hline $\begin{array}{l}\text { Time for } 1 \text { compaction } \\
\text { pass (full area) }\end{array}$ & 10.00 & hrs & $\begin{array}{l}\text { Wattage of welding } \\
\text { equipment }\end{array}$ & 1.80 & kW \\
\hline Number of passes / layer & 6.00 & & Welding speed & 2.50 & $\mathrm{~m} / \mathrm{min}$ \\
\hline compaction time & 240.00 & hrs & Welding time & 14.67 & hrs \\
\hline \multirow[t]{8}{*}{ Fuel consumed } & 3840.00 & I & Fuel consumption & 0.62 & $\mathrm{l} / \mathrm{hr}$ \\
\hline & & & Total Fuel & 9.64 & $\mathrm{I}$ \\
\hline & & & Welding emissions & 0.03 & $\mathrm{tCO}_{2} \mathrm{e}$ \\
\hline & & & $\begin{array}{l}\text { Time for } 1 \text { compaction } \\
\text { pass (full area) }\end{array}$ & 10.00 & hrs \\
\hline & & & Number of passes / layer & 1.00 & \\
\hline & & & compaction time & 10.00 & hrs \\
\hline & & & Fuel consumed & 160.00 & I \\
\hline & & & $\begin{array}{l}\text { Subgrade compaction } \\
\text { emissions }\end{array}$ & 0.42 & $\mathrm{tCO}_{2} \mathrm{e}$ \\
\hline $\begin{array}{l}\text { Clay compaction } \\
\text { emissions }\end{array}$ & 9.98 & $\mathrm{tCO}_{2} \mathrm{e}$ & $\begin{array}{l}\text { Total for geosynthetic } \\
\text { construction }\end{array}$ & 0.44 & $\mathrm{tCO}_{2} \mathrm{e}$ \\
\hline
\end{tabular}


Table 27.11 Example 3 - Calculated embodied carbon emissions for the geosynthetic and clay landfill capping solutions

\begin{tabular}{|l|c|c|c|c|}
\hline & \multicolumn{4}{|c|}{ Embodied Carbon emissions $\left(\mathbf{t C O}_{\mathbf{2}} \mathbf{e}\right)$} \\
\hline Solution & Embodied & Transport & Construction & Total \\
\hline Clay & 6.00 & 31.23 & 9.98 & 47.22 \\
\hline Geosynthetic & 31.28 & 0.31 & 0.44 & 32.03 \\
\hline
\end{tabular}

